\title{
An Unusual and Massive Bloom of Tetraselmis Sp. in the Valparaiso Bay, Chile
}

\author{
Marlene Pizarro ${ }^{1 *}$, Rodolfo Iturriaga ${ }^{2}$, Alejandro Silva ${ }^{3}$ and Sonia Gallegos ${ }^{4}$ \\ ${ }^{1}$ Centro de Investigación y Gestión de Recursos Naturales (CIGREN), Universidad de Valparaíso, Chile \\ ${ }^{2}$ Department of Biological Sciences, University of Southern California, USA \\ ${ }^{3}$ Department of Oceanografia Física, Universidad Católica de Valparaíso, Chile \\ ${ }^{4}$ Naval Research Laboratory, Ocean Sciences, USA
}

Submission: March 26, 2018; Published: May 24, 2018

Corresponding author: Marlene Pizarro, Centro de Investigación y Gestión de Recursos Naturales (CIGREN), Universidad de Valparaíso, Chile, Email: marlene.pizarro@uv.cl

Abstract

An intense bloom of Tetraselmis sp., producing strong water discoloration was observed from December 28th of 2005 through January

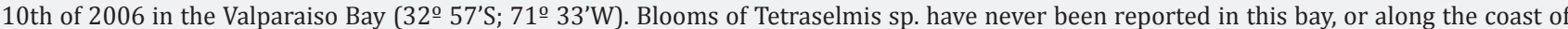
Chile. The confluence of a series of environmental conditions observed before and during the bloom such as: high solar radiation, anomalous UV radiation levels, high sea surface temperatures, water stratification and high nutrient concentrations may have contributed to the development of this unique event.

Keywords: Bloom tetraselmis sp; High solar irradianc; Positive UV anomaly; Valparaiso bay; Chile

\section{Introduction}

Algal blooms are recurring events in coastal regions frequently associated with high nutrients concentrations, particularly of phosphorus and nitrogen. In the Valparaiso Bay, southwesterly winds prevail during the spring and early summer producing upwelling conditions and sporadic phytoplankton blooms, often composed by small diatoms [1]. Blooms of Tetraselmis sp., a microflagellate of the group Prasinophyceae, have never been observed in the Valparaiso Bay waters, or along the coast of Chile. In the Southern Hemisphere only two massive Tetraselmis sp. blooms, producing intense water discoloration have been reported; the first at the Frank Kitts Lagoon, Wellington Harbor, New Zealand on December 10th of 1993, the second at the Saldanha Bay, South Africa on January $15^{\text {th }}$ of 2003 [2,3]. During the bloom at Frank Kitts Lagoon, Tetraselmis sp., reached concentrations from $7.7 \times 102$ to $1.9 \times 103$ cells $\mathrm{mL}^{-1}$, other small flagellates such as, Cryptomonas spp. and Pyramimonas spp. were observed at lower concentrations $(3.2 \times 102$ to $5.5 \times 102$ cells $\mathrm{mL}$ ${ }^{1}$ ). Water surface temperatures were between $15{ }^{\circ} \mathrm{C}-15.8{ }^{\circ} \mathrm{C}$, and this was the only environmental parameters measured. During the Saldanha bay bloom, only visual observations were reported. In the Northern Hemisphere, small blooms of Tetraselmis sp. have been frequently observed during the summer at the site of the Harmful Algal Bloom Monitoring Program of the Southern California Coastal Ocean Observing System, San Diego, California (SCCOOS).

The Valparaiso Bay Tetraselmis sp. bloom developed on December $28^{\text {th }}$ of 2005 , after a period of calm winds, high solar irradiance, and nutrient concentrations (Nitrates over $30 \mu \mathrm{mL}$ ${ }^{1}$ and Phosphates $20 \mu \mathrm{mL}^{-1}$ ), cell densities were up to $300 \times 103$ cellmL ${ }^{-1}$. The bloom reached a large spatial distribution until January $6^{\text {th }}$, when nutrient concentrations were near depletion (Phosphates dropped between 0.8-0.3 30 $\mathrm{mL}^{-1}$ and Nitrates below detection). The bloom ended by January $10^{\text {th }}$ of 2006 .

\section{Materials and Methods}

Surface water samples were collected daily from the $2^{\text {nd }}$ to the $6^{\text {th }}$ of January in 2006 at four stations along the Valparaiso Bay coast (Figure 1).

\section{Spectral absorption of suspended particulate matter}

The spectral absorption of suspended particulate matter $\operatorname{Ap}(\lambda)$ was determined according to Mitchell [4]. Water samples 
( $25 \mathrm{ml}$, due to the high cell concentrations) were filtered onto Whatman GF/F filters at low vacuum pressure $(<2 \mathrm{mmHg})$. The spectral absorption was determined with a double beam UV-VIS Shimadzu-2500 spectrophotometer. A filter saturated with $0.2 \mu \mathrm{m}$ filtered seawater was used as a blank reference. The contribution of detrital particulates to the total $\mathrm{Ap}(\lambda)$ was determined according to Kishino [5]. The absorption coefficients were calculated using the path-length amplification factor $\beta(\lambda)$ described by Mitchell [4].

For data comparison, in situ chlorophyll a, was determined using the relationship between the chlorophyll a specific absorption coefficient (a*pchl a $(\lambda)$ ) and $\operatorname{Ap}(\lambda)$ at $675 \mathrm{~nm}$, as follows: $\left(a^{*}\right.$ pchl a $(\lambda)=A p(\lambda) / c h l$ a). A specific absorption coefficient of 0.02 for chlorophyll a was used, thereby making chl $\mathrm{a}=\operatorname{Ap}(\lambda) / 0.02)[6,7]$. Concentrations were expressed in $\mathrm{mg} \mathrm{chl}$ $\mathrm{a} \mathrm{m}^{-3}$.

\section{Environmental parameters}

Ultra violet radiation (UVR) data were provided by the UV monitoring Station Campbell CR 10X, located $60 \mathrm{~m}$ above sea level at the Universidad Federico Santa María (3302'05"S; $71^{\circ} 35^{\prime} 44^{\prime \prime} W$ ). This station is equipped with NR-LITE-CNR1 sensors. UVA and UVB levels are registered every 10 minutes year-round. Sea surface water temperatures and wind data were provided by the Servicio Hidrográfico y Oceanográfico (SHOA), Armada de Chile, and the Gobernación Marítima de Valparaíso, respectively. The first station is located at 330 $01^{\prime}$ 38" S, 71응

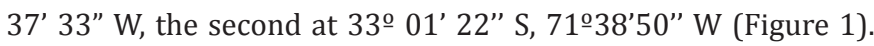
Nutrient concentrations were reported by Collantes \& Prado [8]. Data for water column temperatures and light attenuation coefficients (Kd) determined with a Secchi disc, were provided by the Universidad de Valparaíso.

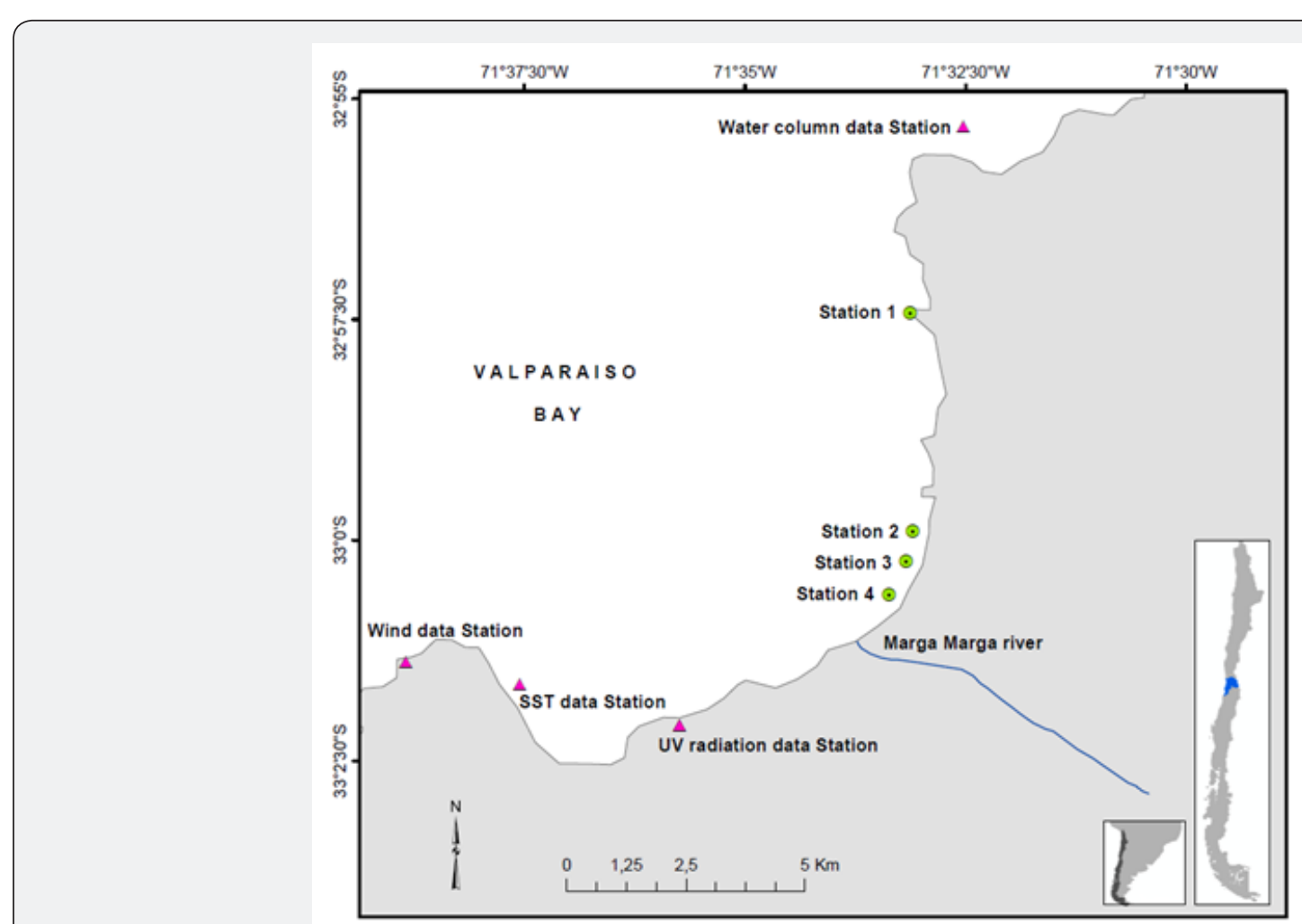

Figure 1: Location of water sampling (green icons), water temperatures, winds and UV radiation stations (pink icons).

\section{Satellite imagery}

An image acquired by the Moderate Resolution Imaging Spectroradiometer (MODIS/AQUA), during a pass on January 9th of 2006 over the Valparaiso Bay, was utilized to estimate Chlorophyll concentrations and geographical distribution. MODIS level $1 \mathrm{~b}$ products from this image were obtained from the NASA archives and converted into Chlorophyll a, using the Automated Processing System (APS) at the Naval Research Laboratory, Stennis Space Center, Mississippi (NRL-SSC). This is a fully automated software package able of processing data for most of the ocean color sensors, delivering accurate Level III and IV products [8,9].

\section{Results}

\section{Spectral Absorption of suspended particulate matter}

The bloom was unique for its magnitude and monoculture type resemblance as shown by the $\operatorname{Ap}(\lambda)$ and shape of the spectra. The $\operatorname{Ap}(\lambda)$ values reflect the cell concentrations and the shape of the spectra, which highlights the absorption peaks of chlorophyll a, at $440 \mathrm{~nm}$ and $675 \mathrm{~nm}$, and chlorophyll b at $470 \mathrm{~nm}$ and $650 \mathrm{~nm}$. Chlorophyll $b$ is distinctive of the Prasinophyceae taxonomic group. These spectral markers were observed in all samples during the bloom (Figure 2). 


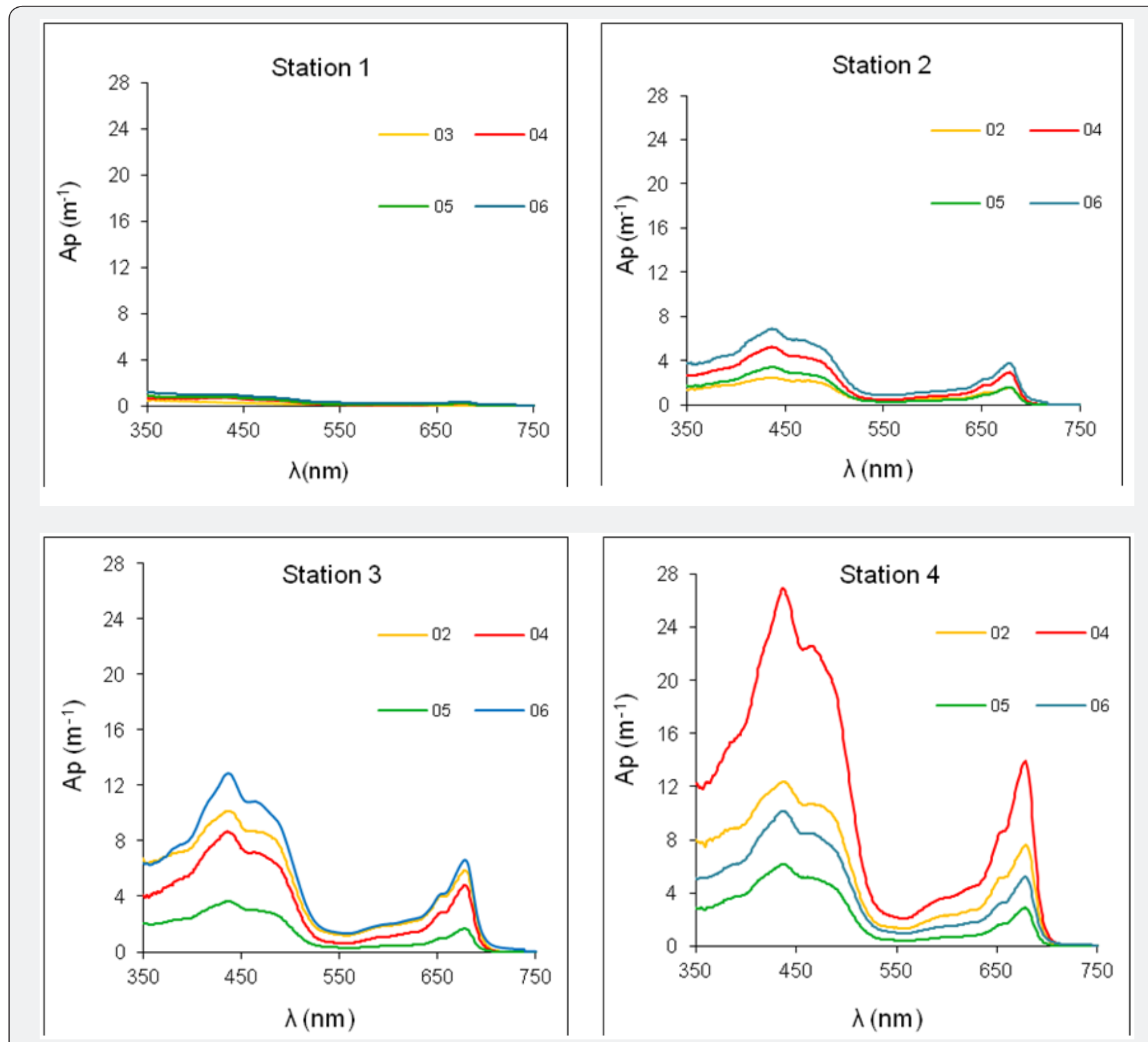

Figure 2: Spectral absorption of suspended particulate matter Ap $(\lambda)$, collected at the four stations in the Valparaiso bay between the $2^{\text {nd }}$ and $6^{\text {th }}$ of January 2006 (dates are outlined in colors).

The contribution of detrital matter to the total Ap $(\lambda)$ was low ( 0.2 to $0.8 \mathrm{~m}^{-1}$ at $350 \mathrm{~nm}$ and less than half at $450 \mathrm{~nm}$ ), indicating that cellular material was one of the main components within the suspended particulate matter.

The maximum Ap $(\lambda)$ values were observed at station 4 on January $4^{\text {th }}$. This site is located in the proximity of the Marga Marga river small outfall, where conditions for a higher proliferation of Tetraselmis sp. appeared to be optimal that day. The lowest Ap $(\lambda)$ values were observed at Station 1. Chlorophyll a in vivo concentrations estimates ranged between 11 to $18 \mathrm{mg} \mathrm{m}^{-3}$ at Station 1, between 78 to $142 \mathrm{mg} \mathrm{m}^{-3}$ at Station 2, between 82 to $292 \mathrm{mg} \mathrm{m}^{-3}$ at Station 3 and from $237 \mathrm{mg} \mathrm{m}^{-3}$ to a maximum of $678 \mathrm{mg} \mathrm{m}^{-3}$ at Station 4 (Figure 2).

\section{UVA-UVB radiation}

During the pre-bloom period (December $14^{\text {th }}$ through the $27^{\text {th }}$ of 2005), UVA levels increased from 3.11 to $5.8 \mathrm{~mW} \mathrm{~cm}^{-2}$ and

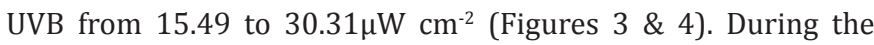
bloom period (December $28^{\text {th }}$ to approximately January $10^{\text {th }}$ ), UVB radiation continued to rise up to $36.94 \mu \mathrm{W} \mathrm{cm}^{-2}$ on January $6^{\text {th }}$ of 2006, while UVA levels remained steady. During the pre-and bloom periods, UVA and UVB reached their highest intensities at midday. 


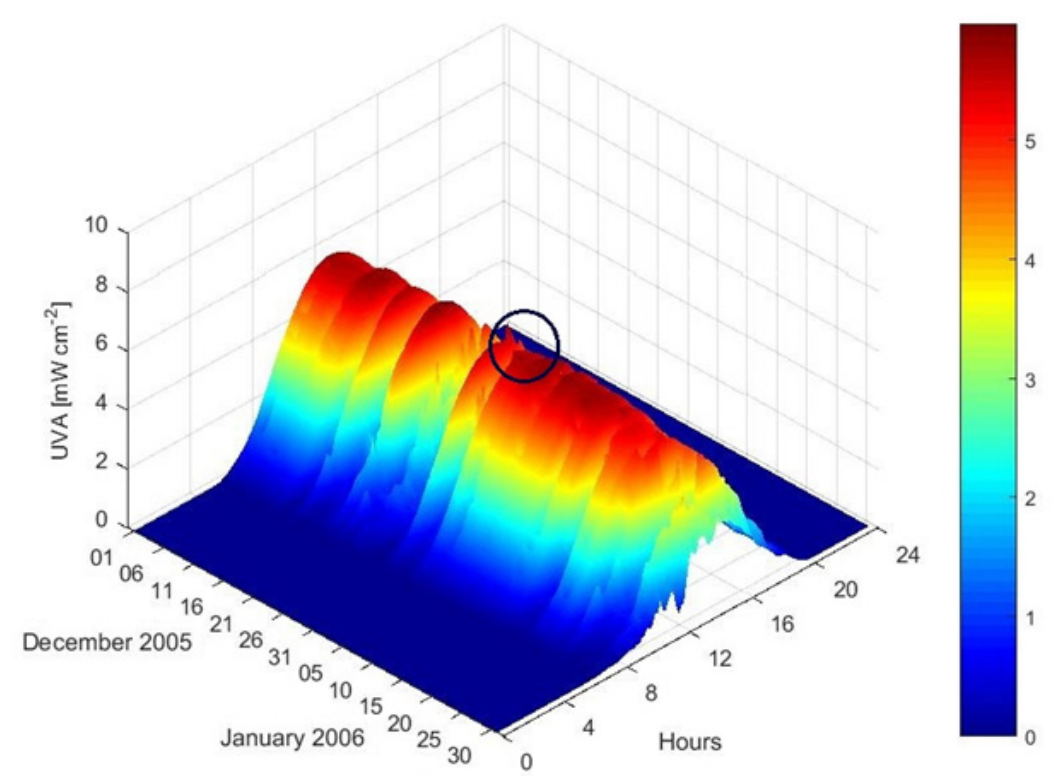

Figure 3: Daily fluctuations of UVA intensity $\left(\mathrm{mW} \mathrm{cm}^{-2}\right)$. Bloom period under the circle.

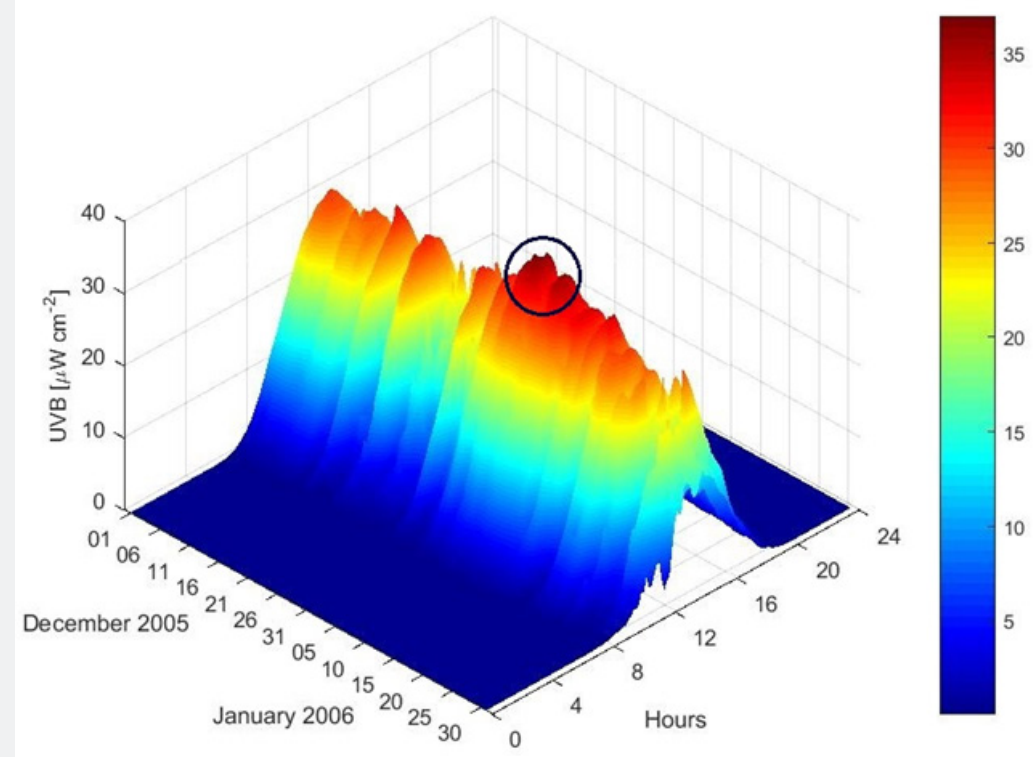

Figure 4: Daily fluctuations of UVB intensity $\left(\mu \mathrm{W} \mathrm{cm}{ }^{-2}\right)$. Bloom period under the circle.

Data collected from 2001 through 2006 during the months of January and July were used to determine the patterns of UVR levels at different times scales (daily, monthly, annually) and to select the periods when the maximum and minimum UVA and UVB intensities were above the average. At mid latitudes, the months of January and July represent the highest and the lowest solar radiation levels registered during all seasons. An anomaly refers to values that are above average (positive anomaly), or below (negative anomaly) within a period. The daily anomaly for the Valparaiso bay was calculated using an average of the daily UVA and UVB radiation levels.

During the pre-bloom period, short-term anomalies for UVA and UVB were registered. However, during the bloom period the magnitude of the positive anomaly for UVB remained in the order of $\sim 2.5-5 \mu \mathrm{W} \mathrm{cm}{ }^{-2}$, the UVA anomaly remained without major changes at $0.5 \mathrm{~mW} \mathrm{~cm}^{-2}$ (Figure 5). 


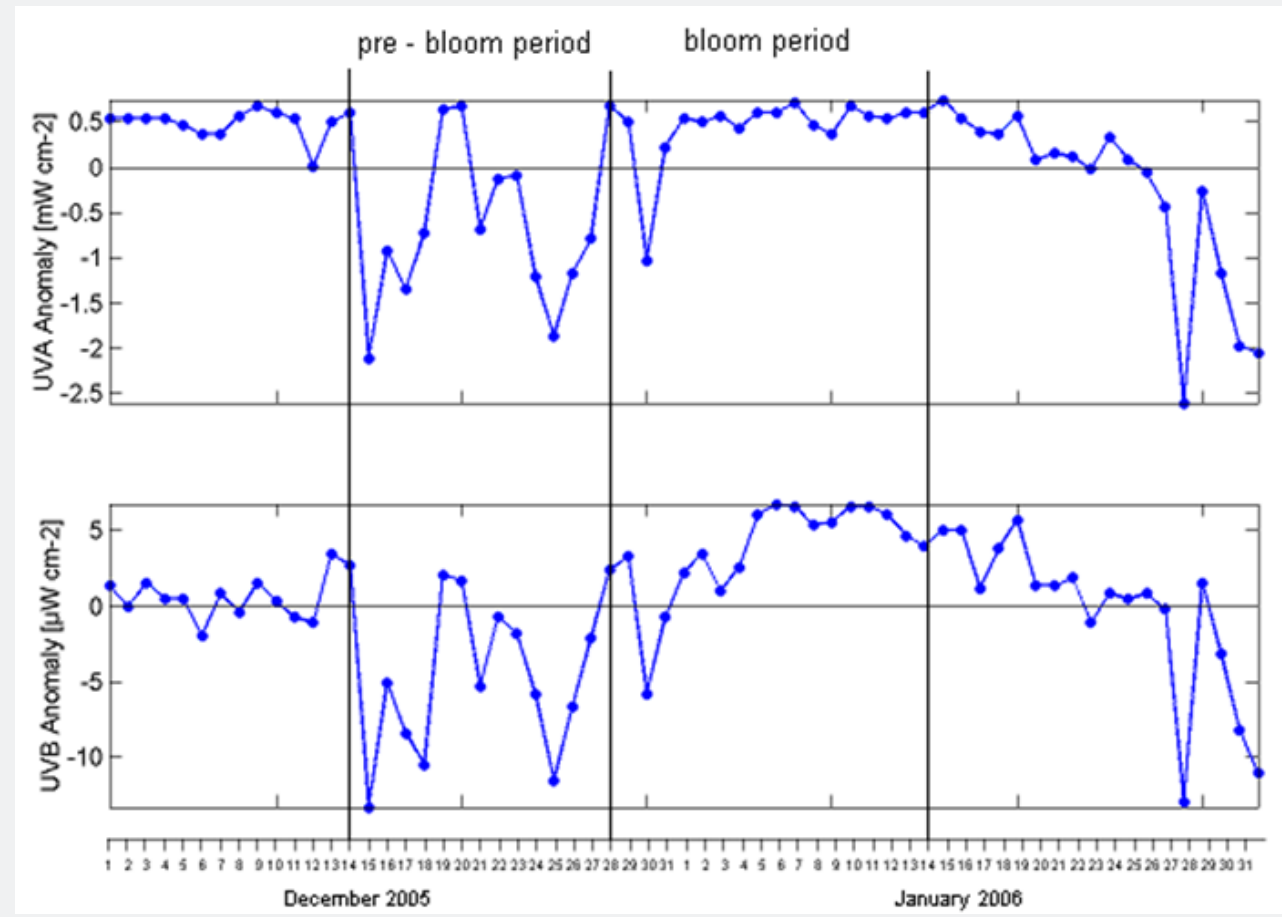

Figure 5: UVA and UVB radiation anomaly before and during the bloom.

\section{Light attenuation coefficient (Kd):}

The high Kd values observed in the coastal areas indicated that Tetraselmis sp. cells reached their maximal growth at the surface and remained in the upper surface during the bloom, restricting the euphotic zone to the upper 3.5 meters. Photosynthetic activity of non-motile phytoplankton (e.g., diatoms) unable to migrate to the surface, may have been affected by the low light levels prevailing below that depth (Figure 6). Previous Kd values for the Valparaiso Bay fluctuated between $0.68 \mathrm{~m}^{-1}$ and $0.1 \mathrm{~m}^{-1}[9]$.

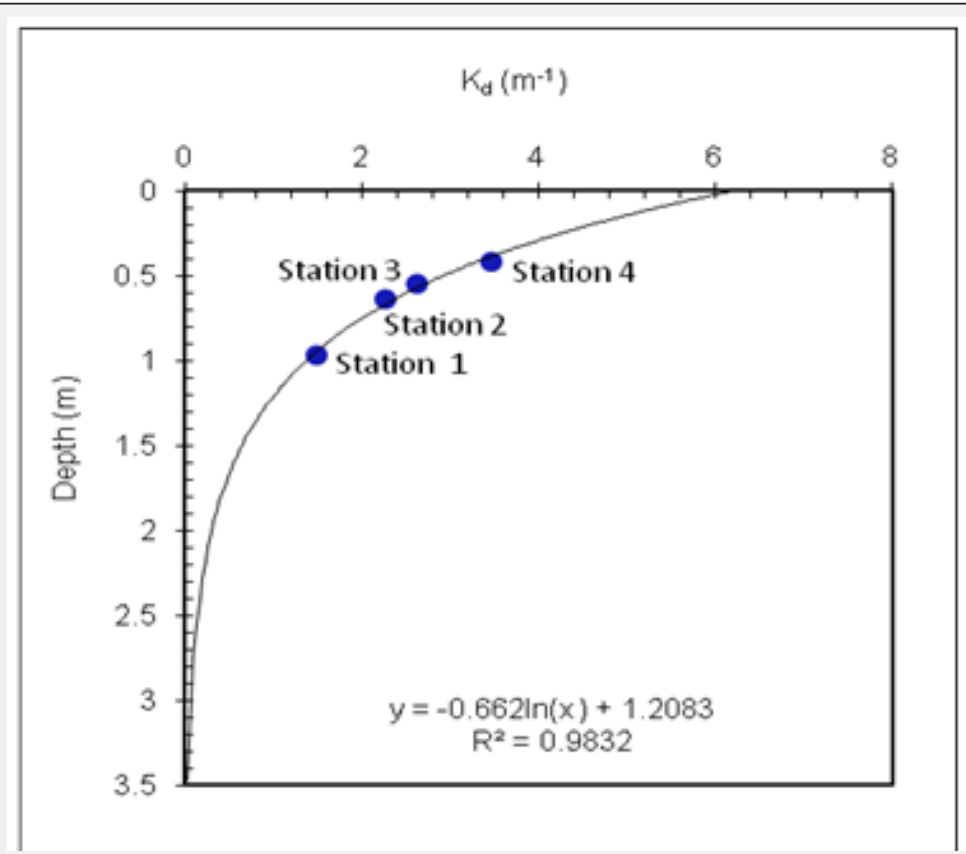

Figure 6: Light attenuation coefficient $\mathrm{Kd}\left(\mathrm{m}^{-1}\right)$ from January 4-6 of 2006.

\section{Sea surface temperature}

During the pre-bloom period, sea surface temperatures oscillated between $16{ }^{\circ} \mathrm{C}$ and $18.6{ }^{\circ} \mathrm{C}$. During the bloom period, they reached a maximum of $19^{\circ} \mathrm{C}$ on January $6^{\text {th }}$ (Figure 7). 


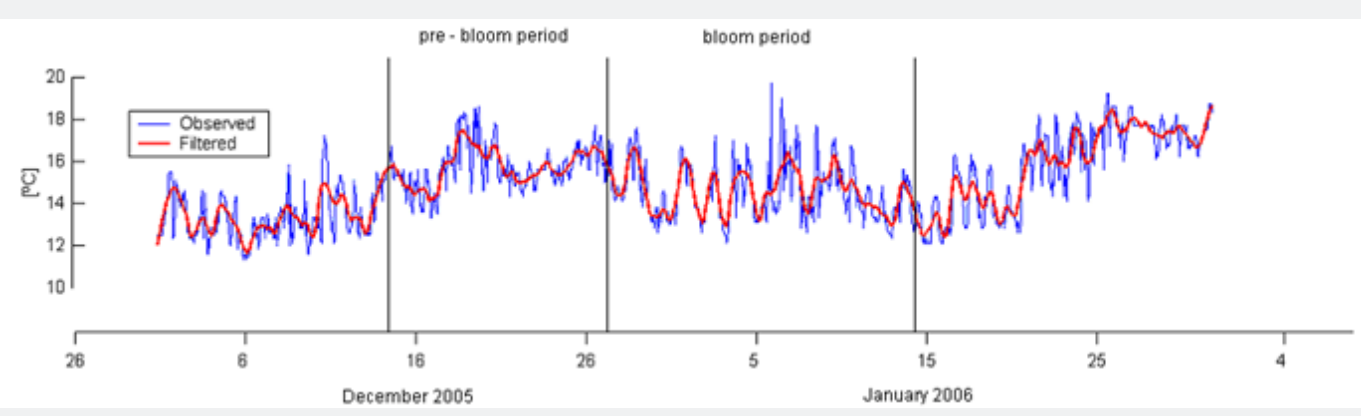

Figure 7: Continuous sea surface temperature $\left({ }^{\circ} \mathrm{C}\right)$ measured before and during the bloom. The blue line is the temperature observed and the red line corresponds to mathematically filtered values.

A water temperature profile performed near the coast on December $27^{\text {th }}$ indicated that a distinctive thermocline had started to develop at $16 \mathrm{~m}$ depth. Taking into account that sea surface temperatures continued to increase until January $6^{\text {th }}$, a shallower thermocline and mixed layer are expected to have developed in the coastal waters of the bay (Figure 8).

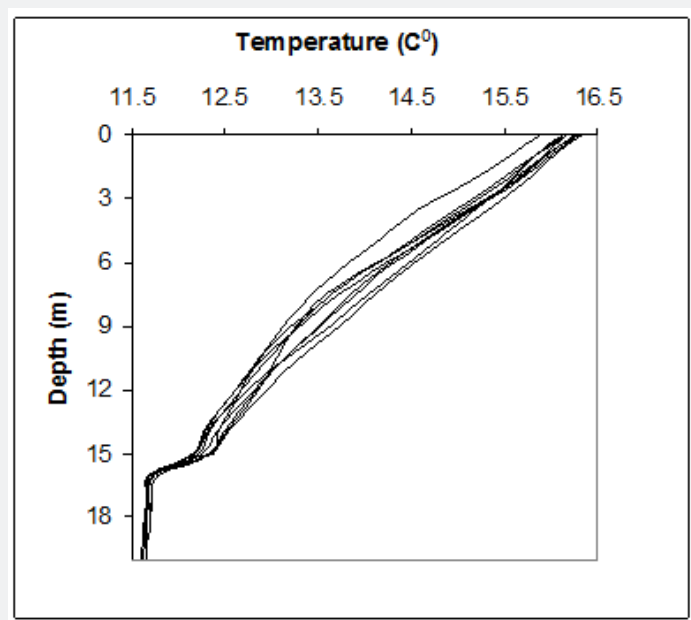

Figure 8: Vertical profiles of water temperatures during the pre-bloom period near Station 1.

\section{Winds}

During the pre-bloom period, weak southwesterly (SW) and northerly $(\mathrm{N})$ winds predominated. Daily wind speed averaged from $1.85 \mathrm{~ms}^{-1}$ to $5 \mathrm{~ms}^{-1}$, remaining calm during the bloom period.
By January $10^{\text {th }}$ the wind direction (SW) increased over $13 \mathrm{~m} \mathrm{~s}^{-1}$, coinciding with the end of the bloom (Figure 9). Wind speeds within the range of $15-20 \mathrm{~m} \mathrm{~s}^{-1}$ generate upwelling conditions in the Valparaiso Bay [10-14].

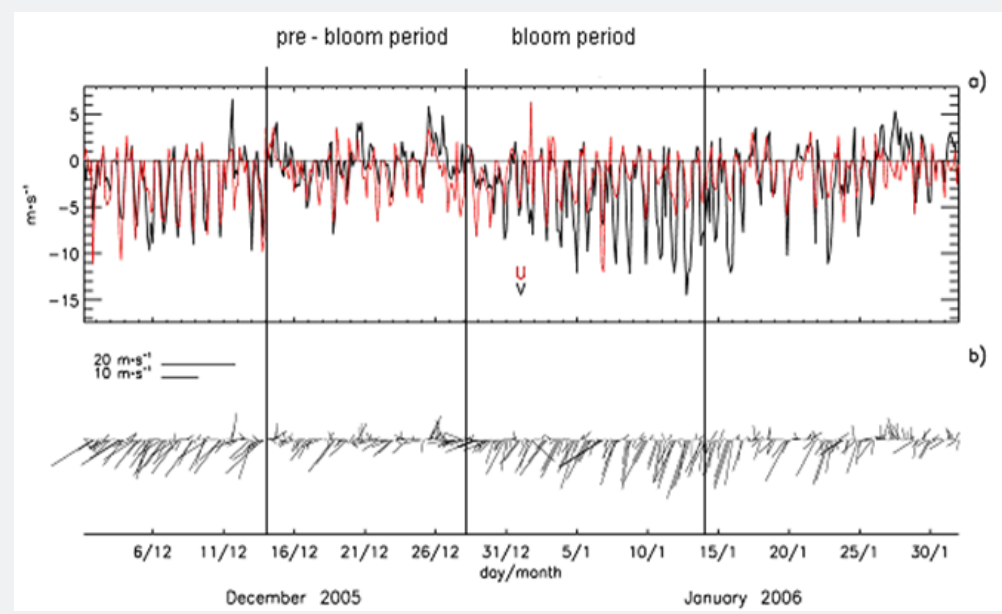

Figure 9: (a) Wind speed $\left(\mathrm{m} \mathrm{s}^{-1}\right)$ and (b) wind direction (degrees), before and during the bloom. Black line (V) corresponds to the N-S winds component and the red line $(U)$ corresponds to the $W-E$ winds component 


\section{Remote sensing analyses}

The MODIS/AQUA image illustrates the extent and distribution of the bloom spreading latitudinally along the coast of the Valparaiso Bay from $32^{\circ}$ to $34^{\circ} \mathrm{N}$, and longitudinally from the coast line to $72^{\circ} \mathrm{W}$. As a result of the high chlorophyll concentrations in the coastal waters (above $4.0 \mathrm{mg} \mathrm{m}^{-3}$ ), the color gradient fell out of scale. In offshore waters, chlorophyll estimates were in the range of $0.2 \mathrm{mg} \mathrm{m}^{-3}$, with fringes extending to the north and south. However, no in situ chlorophyll determinations were performed to cross-validate these estimates (Figure 10).

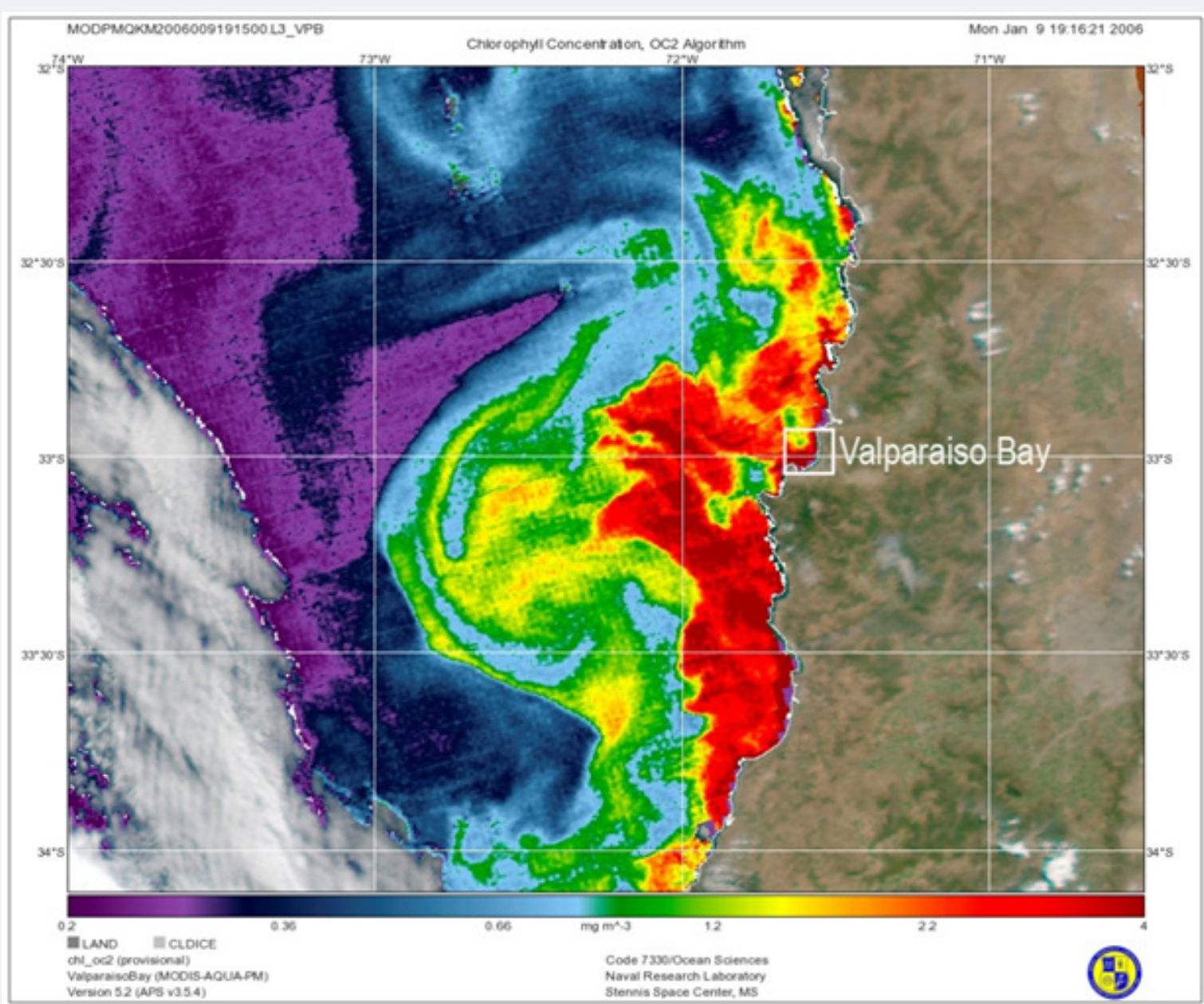

Figure 10: MODIS/AQUA image illustrating the distribution of chlorophyll during the Tetraselmis $s p$. bloom in the Valparaiso Bay region, January $9,2006$.

There was an indication of a clockwise circulation delineated by the chlorophyll concentrations between 1 and $2 \mathrm{mg} \mathrm{m}^{-3}$. The presence of such cold eddies may have had some role in the encroachment of coastal waters during the pre-and bloom periods. Outside of the eddy-like circulation, chlorophyll concentrations were below $0.5 \mathrm{mg} \mathrm{m}^{-3}$, values commonly observed in offshore waters of this region. However, due to the extensive cloud cover, common along the coast of Chile, it was not possible to follow the development of eddies from satellite imagery.

\section{Discussion}

The Valparaiso Bay Tetraselmis sp. bloom occurred in the middle of the summer season of the southern hemisphere. The bloom developed rapidly after a period of wind relaxation, high solar irradiance, higher water temperatures, stratification of the upper water column, as well as high nutrient concentrations. The confluence of all these factors, in addition to a positive UVR anomaly may have provided a unique scenario for the development of this massive bloom.

A comparison of previous records of sea surface temperatures in the Valparaiso Bay during December and January indicated an average within $15-17{ }^{\circ} \mathrm{C}[11,14]$. During the pre-bloom period of Tetraselmis sp., sea surface temperatures registered $18{ }^{\circ} \mathrm{C}$, reaching $19{ }^{\circ} \mathrm{C}$ during the bloom. Nutrient concentrations during the pre-bloom period was in the order of $30 \mu \mathrm{m} \mathrm{L}^{-1}$ and $46 \mu \mathrm{m} \mathrm{L}^{-1}$ for nitrate and phosphate respectively. Such high concentrations facilitated the high cell density observed along the coast of the bay during the bloom. At Station 4, cell concentrations reached $300 \times 103$ cell mL ${ }^{-1}$, with chlorophyll a values of $642 \mathrm{mg} \mathrm{m}^{-3}$. These 
values superseded an intense red tide bloom of Lingulodinium polyedra observed in La Jolla, California, in 1995, where cell concentrations reached $20 \times 103$ cell mL $\mathrm{m}^{-1}$ and surface chlorophyll a exceeded $100 \mathrm{mg} \mathrm{m}^{-3}$, with one observation reaching $500 \mathrm{mg} \mathrm{m}^{-3}$ [15]. Several dinoflagellate blooms with cell concentrations in the order of $2 \times 103$ cell $\mathrm{mL}^{-1}$ and chlorophyll a values of $500 \mathrm{mg}$ $\mathrm{m}^{-3}$, were reported for this same area during 1964, 1965 and 1966 [16]. In the Valparaiso Bay, during a typical spring season upwelling, previous data for nutrient concentrations indicated values between 3 and $9 \mu \mathrm{mL}^{-1}$ for nitrate and between 2 and $3 \mu \mathrm{mL}^{-1}$ for phosphates. However, chlorophyll a concentrations fluctuated between 0.9 to $31 \mathrm{mg} \mathrm{m}^{-3}$ [13]. During the Valparaiso Bay pre-bloom period nitrates and phosphates reached values over $30 \mu \mathrm{mL}^{-1}$ and $20 \mu \mathrm{mL}^{-1}$. Wind speed measured during the preand bloom periods remained calmed facilitating water column stratification, only near the end of the bloom wind speed reached values over $13 \mathrm{~m} \mathrm{~s}^{-1}$, typical upwelling conditions for the Valparaiso Bay develop when wind speeds reach between $15-20 \mathrm{~m} \mathrm{~s}^{-1}$ [13].

The high attenuation coefficient, $\mathrm{Kd}\left(\mathrm{m}^{-1}\right)$, observed during the Valparaiso Bay bloom indicated that Tetraselmis sp. cells proliferated and remained approximately in the upper 3 meters. Photosynthetic activity of non-motile species (e.g. diatoms) unable to migrate to the surface may have been affected by the low light levels prevailing below that depth (Kd values at Station 1 and station 4 , between $1.5 \mathrm{~m}^{-1}$ to $3.5 \mathrm{~m}^{-1}$, respectively). The values were much higher when compared to previous Kd measurements for the bay that fluctuating between $0.68 \mathrm{~m}^{-1}$ and $0.1 \mathrm{~m}^{-1}$ [10].

Another factor to be considered was the high UVR levels and positive UV anomaly observed before and during the bloom. Photosynthesis is affected by the levels of photosynthetically active radiation (PAR: 400-700nm) and ultraviolet radiation (UVR: 290$400 \mathrm{~nm}$ ) penetration in the upper water column. Excessive PAR and UVR inhibit photosynthesis and damage cellular components [17-22]. UVB (290nm-320nm) radiation has raised concerns for its effects on marine ecosystems [23,24]. An increase in UVB can alter species composition and standing crop of microalgae [25-27]. Though, species with micosporin-like-aminoacids (MAA) cellular content are more tolerant to higher UVB levels [24,28-30]. Previous studies have indicated that Tetraselmis sp. is able to sustain and grow under higher UVR levels than other phytoplankton. Experimental data showed no evidence of delay in cellular division of Tetraselmis sp. under solar radiation dosages of $416 \mathrm{cal} \mathrm{cm}^{-2} \mathrm{~d}^{-1}$ for five days, showing a high tolerance to UVR [25]. Furthermore, a study about the relative sensitivity to UVB by Tetraselmis suecica, showed no inhibition to dosages of $0.4 \mathrm{Wm}^{-2}$ [31]. These studies suggest that under experimental conditions this specie is tolerant to higher UVR levels $[32,33]$. However, the extent of UVR damage to the phytoplankton community, has not yet been resolved [34].

\section{Conclusion}

Information about Tetraselmis sp. massive blooms are restricted to the few previous observations, they are also limited by the lack of long-term oceanographic data available, including the one observed at the Valparaiso Bay. Therefore, it is difficult to formulate unambiguous conclusions without falling into speculations. Although, we can assume that the simultaneous confluence of high solar irradiances, sea surface temperatures, water column stratification, high nutrient concentrations, and a positive UV anomaly after a period of wind relaxation, facilitated the rapid growth Tetraselmis sp., outpacing other species. A relevant feature about this bloom, was provided by the MODIS/ Aqua image revealing the magnitude and distribution of this bloom. What remains unknown is the phytoplankton composition beyond the Valparaiso Bay coastal waters.

\section{Acknowledgement}

We thank Drs. Mario Caceres, Roberto Prado and Gloria Collantes, Facultad de Ciencias del Mar y Recursos Naturales, Universidad de Valparaíso, Drs. Roberto Sota and Luis Da Silva, Universidad Santa Maria. We also thank the Servicio Hidrográfico y Oceanográfico de la Armada de Chile and the Gobernación Marítima de Valparaíso for their collaboration. We extend our gratitude to the NRL's Slope to Shelf Energetics and Exchange Dynamics project and Mr. S. Ladner for MODIS data processing. This work was supported by the MECESUP-Chile Program.

\section{References}

1. Avial A, S Avaria (1982) Proliferación de primavera del fitoplancton en la Bahía de Valparaíso. II. Dinámica de las comunidades. Rev Biol Mar 18(1): 1-56.

2. Jones B, Rhodes L (1994) Suffocation of pilchards (Sardinops sagax) by a green microalgal bloom in Wellington Harbor, New Zealand. Jour Mar Fresh Res 28: 379-383.

3. Sym S, Khosa F, Marangoni C, Pitcher GC (2004) On the identity of a bloom forming Tetraselmis species from Saldanha bay. $20^{\text {th }}$ Congress of the Phycological Society of Southern Africa. South Africa.

4. Mitchell BG (1990) Algorithms for determining the absorption coefficient of aquatic particulates using the quantitative filter technique (QFT). Ocean Optics X 1302: 137-148.

5. Kishino M, Takahashi M, Okami N, Ishimuran S (1976) Estimation of the spectral absorption coefficients of phytoplankton in the sea. Bull Mar Sci 37(2): 634-642.

6. Iturriaga R, Siegel D (1989) Microphotometric characterization of phytoplankton and detrital absorption properties in the Sargasso Sea. Limnol Oceanogr 34(8): 1706-1726.

7. Kahru M, Michell G (1998) Spectral reflectance and absorption of massive red tide off southern California. Jour Geophys Res 103(10): 21601-21609.

8. Collantes G, Prado R (2006) Green bloom of Tetraselmis sp. in Valparaiso Bay. In: Tim Wyatt (Ed.), Harmfull Algae New № 30. The Intergovernmental Oceanographic Commission. UNESCO, USA, p. 12.

9. Martinolich P (2006) Automated Satellite Processing System User's Guide 1257 Version 3.4. Washington DC, USA.

10. Ladner SD, Sandidge JC, Lyon PE, Arnone RA, Gould RW, et al. (2008) Development of finer spatial resolution optical properties from MODIS. Proc of SPIE 6680: 668013.

11. Pizarro M (1973) Estudios de ecología fitoplanctónica en la Bahía de Valparaíso. I. La temperatura superficial y la radiación solar. Rev Biol Mar 15: 77-105 
12. Avaria S (1971) Variaciones mensuales del fitoplancton de la Bahía de Valparaíso entre Julio de 1963 y Julio 1966. Rev Biol Mar 14(3): 15-43.

13. Avial A, Avaria S (1981) Proliferación de primavera del fitoplancton en la Bahía de Valparaíso. I. Condiciones meteorológicas y oceanográficas. Rev Biol Mar 17(2): 197-227.

14. Avaria S, Muñoz P (1982) Producción actual, biomasa y composición esporádica del fitoplancton de la Bahía de Valparaíso en 1979. Rev Biol Mar 18(2): 129-157.

15. Sievers H, Vega S (2000) Respuesta físico-química de la bahía de Valparaíso a la surgencia generada en Punta Curaumilla y al fenómeno El Niño. Rev Biol Mar Oceanograf 35(2):153-168.

16. Holmes RW, Williams PM, Eppley RW (1967) Red water in La Jolla Bay, 1964-1966. Limnol Oceanogr 12: 503-512.

17. Karentz D, McEuen F, Land M, Dunlap W (1991) Survey of mycosporinelike amino acid compounds in Antarctic marine organisms: potential protection from ultraviolet exposure. Mar Biol 108: 157-166.

18. Prézelin B, Boocher N, Schofield O (1994) Evaluation of field studies of UVB radiation effects on Antarctic marine primary productivity. Stratospheric ozone depletion/ UV-B radiation in the biosphere pp. 181-194.

19. Helbling W, Avaria S, Letelier J, Montecinos V, Ramírez B, et al. (1993) Respuesta del fitoplacton marino a la radiación ultravioleta en latitudes medias (33을. Rev Bio Mar 28(2): 219-237.

20. Helbling W, Bruma A, Karin M, Villafañe V (2001) In situ impact of solar ultraviolet radiation on photosynthesis and DNA in temperate marine phytoplankton. Mar Ecol Prog Ser 211: 43-49.

21. Helbling W, Barbieri ES, Marcoval MA, Gonçalves RJ, Villafañe VE, et al. (2005) Impact of Solar Ultraviolet Radiation on Marine Phytoplankton of Patagonia, Argentina. Photochem and Photobiol 81(4): 807-818.

22. Modenutti B, Balseiro E, Callieri C, Bertoni R, Queimaliños C, et al. (2005) Effect of UV-B and different PAR intensities on the primary production of the mixotrophic planktonic ciliate Stentor araucanus. Limnol Oceanogr 50(3): 864-871.

23. Gibson J, Vicent W, Nieke B, Pienitz R (2000) Control of biological exposure to UV radiation in the Arctic Ocean: comparasion of the roles of ozone and riverine dissolved organic matter. Arctic 53(4): 372-382.
24. Mohovic B, Gianesella S, Laurion I, Roy S (2006) Symposium-inPrint: UV Effects on Aquatic and Coastal Ecosystems. Ultraviolet B-photoprotection Efficiency of Mesocosm-enclosed Natural Phytoplankton Communities from Different Latitudes: Rimouski (Canada) and Ubatuba (Brazil). Photochem Photobiol 82(4): 952-961.

25. Jokiel PL, York RH (1984) Importance of ultraviolet radiation in photoinhibition of microalgal growth. Limnol Oceanogr 29(1): 192198.

26. Beardall J, Berman T, Markager S, Martinez V, Montecino R, et al. (1997) The effects of ultraviolet radiation on respiration and photosynthesis in two species of microalgae. Can J Fish Aquat Sci 54: 687-696.

27. Montecino V, Molina X, Martínez G, Olmedo M, Retamal L, et al. (2001) Ecophysiological strategies in response to UV-B radiation stress in cultures of temperature microalgae isolated from the Pacific coast of South America. Rev Chil Hist Nat 74(2): 293-311.

28. Montecino V, Pizarro G (1995) Phytoplankton acclimation and spectral penetration of UV irradiance off the central Chilean coast. Mar Ecol Prog Ser 121: 216-269.

29. Whitehead K, Vernet M (2000) Influence of mycosporine-like amino acid (MAAs) on UV absorption by particulate and dissoldev organic matter in La Jolla Bay. Limnol Oceanogr 45(8): 1788-1796.

30. Klisch M, Sinha R, Richter P, Häder D (2001) Mycosporine-like amino acids (MAAs) protect against UV-B-induced damage in Girodinium dorsum Kofoid. Jour Plant Physiol 158: 1449-1454.

31. Montero O, Klisch M, Häder DP, Lubian L (2002) Comparative sensitivity of seven marine microalgae to cumulative exposure to ultraviolet-B radiation with daily increasing doses. Botanica Marina 45(4): 305-315.

32. Goes JI, Handa N, Taguchi S, Hama T (1994) Effect of UV-B radiation on the fatty acid composition on the marine phytoplankter Tetraselmis s.p.: relationship to cellular pigments. Mar Ecol Prog Ser 114: 259-274.

33. Kristoffersen AS, Hamre B, Frette O, Erga SR (2016) Chloroplyll a fluorescence lifetime reveals UV-induced photosynthetic activity in the green algae Tetraselmis. Eur Biophys J 45: 259-268.

34. Vernet M (2000) The effects of UV radiation on the phytoplankton physiology and ecology of marine phytoplankton. In: Mora S, Demers S, Vernet M, (Eds.), The effects of UV radiation in the marine environment. Cambridge Press, UK, pp. 237-278.

\begin{tabular}{l} 
Your next submission with Juniper Publishers \\
will reach you the below assets \\
- Quality Editorial service \\
- Swift Peer Review \\
- Reprints availability \\
- E-prints Service \\
- Manuscript Podcast for convenient understanding \\
- Global attainment for your research \\
- Manuscript accessibility in different formats \\
( Pdf, E-pub, Full Text, Audio) \\
- Unceasing customer service \\
Track the below URL for one-step submission \\
https://juniperpublishers.com/online-submission.php \\
\hline
\end{tabular}

